\title{
Recapitalisation and the Financial Performance of Firms: Empirical Evidence from the Insurance Industry in Nigeria
}

\author{
Augustine Shina Akande ${ }^{1}$ Sunday Eneojo Samuel ${ }^{2 *} \quad$ Baba Yaro Iyodo ${ }^{3}$ \\ 1. Independent Researcher, AXA Nigeria - Lagos \\ 2. School of Business, Law and Social Sciences, Abertay University Dundee, United Kingdom \\ 3. Department of Banking and Finance, Faculty of Management Sciences, University of Jos, Nigeria
}

\begin{abstract}
s
Financial Performance sits at the core of a firm's ability to meet the expectations of its stakeholders and create sustainable value. The history of insurance in Nigeria traces back to the pre-colonial era with the creation of the Royal Exchange Assurance Agency in 1918. The industry, however, is arguably one of the least performing sectors within the Nigerian economy and the financial service sector in particular. Recapitalization reforms have been acknowledged as one of the actions that improve the financial performance of firms, this study, therefore, gauged the impact of recapitalization on the financial performance of the insurance industry in Nigeria. The study adopted the Expected Bankruptcy Cost Hypothesis, Signalling Theory and Risk-Return Hypothesis to underpin the impact of Recapitalisation reforms on the performance of firms. Using Purposive Sampling technique, the study selected the top 12 (contributing 74\% of total insurance industry revenue in 2018) insurance companies in Nigeria from 2009 to 2018 and used annual reports obtained from the company's corporate website to select variables of interest. Using Shareholders Funds (SHF) as a proxy for recapitalization and Gross Written Premium (GWP), Profit before Tax (PBT), Total Assets (TA) and Capital Employed (CE) as proxies for financial performance, Least Square regression result show a positive and substantial relationship between recapitalization and the financial performances of firms. The study, therefore, recommends that the upcoming recapitalization reforms in the insurance sector be embraced by all stakeholders as evidence suggest that the industry would be in a better financial state and well-positioned to take on large/complex in-country risk thereby forestalling capital flight.
\end{abstract}

Keywords: Recapitalisation, Financial, Performance, Insurance, premium

DOI: $10.7176 / \mathrm{EJBM} / 12-23-07$

Publication date:August $31^{\text {st }} 2020$

\section{Introduction}

The insurance industry in Nigeria has passed through many phases of evolution. Some of these changes include but not restricted to the number of players, changes in ownership structure, extension in the breadth and depth of operations and modifications in the regulatory environment. These changes have been triggered by deregulation, globalization, technology and regulatory action. Recapitalization is the process of changing a company's debt and equity mixture to achieve solidity in the capital structure of firms. Recapitalization process would usually involve the trade-off of one form of financing for another such as trading off debt for equity and vice versa (Ugwuanyi, 2012; Alajekwu and Obialor, 2014).

There are several forms of recapitalization some of which are equity recapitalization through the capital market or private equity, nationalization affected recapitalization and leveraged recapitalization also known as leveraged buyouts. In an equity recapitalization, new equity shares are issued to raise funds to be used to influence a recapitalization exercise. Equity recapitalization is beneficial to enterprises with high debt to equity ratios. High debt to equity ratio is a hint of a higher burden on an enterprise because interest must be paid on debt obligations. The increased debt level is less attractive to existing and potential stakeholders it indicates a higher risk position of the firm. Companies, therefore, may seek to reduce its debt burden by issuing new equity shares and using the money raised from that to pay back a portion of its current debt. Private equity recapitalization can be realised through the capital market in which case, publicly listed entities approach the capital market to raise funds or through private equity funds (Alalade, Adekunle and Oguntodu, 2016).

Leveraged buyout recapitalization is a state where recapitalization is realised through borrowed funds. The acquirers use the assets of the target firm as collateral to borrow funds used to effect the recapitalization. Recapitalization is an unplanned consequence of leveraged buyout; the acquiring company does not certainly have an intention to modify the capital structure of the acquired company. However, due to such substantial borrowings, the debt obligation of the acquired company increases, and the capital structure automatically changes leading to recapitalization. There is no evidence of leveraged recapitalization in the insurance industry in Nigeria. Nationalization means converting privately held assets to publicly held asset through policy initiatives. The most notable example of nationalization is the Troubled Asset Relief Program (TARP) introduced by the United States government to float the country's banks in the hit by the 2008 depression. Like leveraged buyout, recapitalization is an unintended consequence as the government's objective is to transfer the ownership of assets from private individuals to the government for strategic reasons (Abubakar, Usman, and Sulaiman, 2018). 
Oloye and Osuma (2015) outlined some specific reasons for consolidation in the banking sector among which are to halt the incessant bout of distress, to promote competitiveness and transparency in the sector, effectively allow the sector play its developmental role in the economy, to fund the sector to be an active participant in the regional and global financial arrangement and to enhance public assurance and support in the industry. Oloye and Osuma (2015) further posit that an insurance company's primary obligation is restorative action, by this he means the restoration of the insured /policyholder back to the condition he was in before a loss and to spread risk through reinsurance. However, an insurance company as other commercial enterprises exist to make a profit by offering indemnity service in exchange for a fee termed 'premium' and providing an array of services to individuals and corporate establishments at a fee. Insurance is a form of risk management primarily used to hedge in contrast to the risk of a contingent loss. Insurance is defined as the equitable transfer of the risk of a loss from one entity to another in exchange for a premium (Iyodo, Samuel and Inyada, 2019).

The National Insurance Commission (NAICOM) revised the minimum paid-up share capital requirement for all classes of the insurer doing business in Nigeria. The new recapitalization guideline requires life insurance business to have 8 billion naira up from 2 billion naira, general insurance business to have 10 billion naira up from 3 billion naira, composite insurance business to have 18 billion naira up from 5 billion naira and Reinsurance business to have 20 billion naira up from 10 billion naira. In the views of Seyi and Oluwatoba (2019), the minimum paid-up capital will have a substantial impact on the Nigerian insurance industry. Given Nigeria's unexploited vast potential in the global insurance marketplace, a well-capitalized industry with insurers who have deep pockets and impressive local capacity is required and will contribute to the success and growth of the Nigerian economy.

A lot of studies have been done on recapitalization and its outcome on financial performance in Nigeria but most of the study covers banking and manufacturing industry and little or none has been done in the insurance space. Many researchers have written about the impact of recapitalization on the financial performance of commercial enterprises but very few works of literature exist on the impact of recapitalization on any performance metrics of the insurance industry (Adegbaju and Olokoyo, 2008). This paper, therefore, analyses the impact of recapitalization on the financial performance of insurance corporations in Nigeria for the period 2009 to 2018 , make a case for the impending recapitalization in the insurance industry and highlight possible benefits to stakeholders. Part of the expected benefit of a recapitalized insurance industry is increasing in the aptitude of insurance companies to underwrite big risks normally referred to as large ticket transactions and increase in insurance policy uptake in the retail space hence this study examines the impact of recapitalization on the financial performance of insurance industry in Nigeria.

The broad objective of this study is to measure the impact of recapitalization on the financial performance of insurance establishments in Nigeria. The specific purpose of the study is to:

i. assess the impact of Recapitalization on the Gross Written Premium (GPW) of insurance companies in Nigeria

ii. assess the impact of Recapitalization on the Profit before Tax (PBT) of insurance companies in Nigeria.

iii. assess the impact of Recapitalization on the Total Assets (TA) of insurance companies in Nigeria.

iv. assess the impact of Recapitalization on the Capital Employed (CE) of insurance companies in Nigeria. From the objectives of the study, the following research hypotheses, in null form, were developed:

$H_{01}$ : There is no significant impact of Recapitalization on the Gross Premium Written (GPW) of insurance companies in Nigeria.

$H_{02}$ : There is no significant impact of Recapitalization on the Profit before Tax (PBT) of insurance companies in Nigeria.

$H_{03}$ : There is no significant impact of Recapitalization on the Total Assets (TA) of insurance companies in Nigeria. $H_{04}$ : There is no significant impact of Recapitalization on the Capital Employed (CE) of insurance companies in Nigeria.

\section{Review of related literature}

The insurance industry grew at a compounded annual growth rate of $10.2 \%$ in premium income since 2012 with investment income reaching an unprecedented high of 54.5 billion and industry return on capital put at $8.4 \%$ (Ufomadu, 2012). The penetration rate, measured as a percentage of GDP, of the Nigerian insurance industry, stood at 0.3 percent; equated with $14.7 \%$ in South Africa; $2.8 \%$ in Kenya; $1.1 \%$ in Ghana; $0.6 \%$ in Angola and $0.6 \%$ in Egypt. Similarly, the density of the Nigerian insurance sector (i.e. the measure of gross premium per capita) is presently at \$6.2 and lags its African equivalent: Egypt (\$22.8); South Africa (\$762.5); Kenya (\$40.5) and Angola (\$30.5) (Seyi and Oluwatoba, 2019; Iyodo et al., 2020).

Similarly, the asset base of the Nigerian insurance sector was at 1.3 trillion naira as at December 31, 2018, representing multiple annual growth rates of $17 \%$ while the Gross Premium Income generated within the period was estimated at 448.6 billion naira, reflecting a $12 \%$ growth rate annually. While these data herald huge growth budding for the Nigerian insurance industry, many insurers are still principally under-capitalized, hence restricting their capability to take on big-ticket local and international risks, as seen in the marine, aviation, oil and gas sectors of the economy. Similarly, Nigerian insurers require supplementary capital to help the procurement of modern 
digital and technology-driven structure necessary to support their efforts in expanding insurance penetration through Insur-Tech (Iyodo, Samuel and Inyada, 2018).

\subsection{Recapitalization}

The recapitalization exercise of the insurance corporations of 2007 pegged tier 1 insurance firm's capitalization base to 5 billion-naira, tier 2 firms at 3-billion-naira capitalization base and tier 3 firms had 2-billion-naira capitalization base requirement. Starting from May 2019, insurance corporations are required to recapitalize in line with the newly released guideline. The new Recapitalisation guideline requires life insurance business to have 8 billion naira up from 2 billion naira, general insurance business to have 10 billion naira up from 3 billion naira, composite insurance business to have 18 billion naira up from 5 billion naira and Reinsurance business to have 20 billion naira up from 10 billion naira (Bakare, 2011; Kari, 2019). According to Kari (2019), recapitalization is desirable because while inflation and interest rates had changed in the last few years, insurers were still operating with the 2007 capitalization guideline. He further argued that the initiative would boost the profitability of insurers through optimal capitalization.

Eddie (2018) added that industry operators have traded to their limit as far as corporate business was concerned insisting that what is needed is to develop the retail segment of the insurance business. In his words, "as an industry, we have traded to the limit, as far as corporate insurance is concerned, all corporate bodies are buying insurance but there is a hard nut at the ray base which is retail". Nobody will dispute that progress has not been made in this direction and insurers' presence has not been felt at the micro or retail level.

A substantial amount of studies have been done on recapitalization and its outcome on financial performance in Nigeria but most of the study covers banking and manufacturing industry and little or none has been done in the insurance space (Iyodo, Samuel and Inyada, 2018). Oloye and Osuma (2015) looked at the influence of Mergers and Acquisition on the financial performance of Nigerian banks. In the study, shareholders fund was used as the predictor and profit after tax as the dependent variable, hence, this study also refers to shareholders fund as a proxy for Recapitalisation. The justification for shareholders fund is premised partly on the fact that the NAICOM preference as evidence of a recapitalized insurance firms is shareholders fund, more importantly, the level of risk an insurance company is licensed to underwrite is also a function of its shareholders' fund. Part of the projected benefit of a recapitalized insurance industry is increasing in the aptitude of insurance companies to underwrite big risks commonly stated as large ticket transactions, and increase in insurance policy uptake in the retail space hence this study examines the impact of recapitalisation on the financial performance of insurance industry in Nigeria.

Adedeji, Babatunde and Adekanye (2015) used the Shareholders Fund (SHF) as a proxy to determine the impact of recapitalization policy on the performance of banks in Nigeria. Shareholders fund for an insurance company is the sum of share capital, share premium, reserves (contingency, fair Value and other reserves) and retained earnings. Shareholders' funds refer to the amount of equity in a company which belongs to the shareholders. The amount of shareholders' funds yields an estimate of how much the shareholders would receive if a business were to liquidate.

Gross Written Premium is the summation of both direct premiums written and assumed premiums written before the effect of ceded reinsurance. Direct premiums were written represents the premiums on all policies the insurance companies have issued throughout the period. Idris (2015) uncovered a positive but insignificant connection between capital size and profitability of insurance business in Nigeria using Profit after Tax (PAT) and gross premium earned as a dependent indicator of financial performance. Gross Premium Written (GWP) was used because it is a more valuable predictor of financial performance as it is an unswerving outcome of dealings in the current accounting period as opposed to Gross Premium Earned (GPE) which would have revenue written in the previous accounting period but earned in the current Accounting period.

Profit before tax (PBT) is a measure that looks at a company's profits before the company pays corporate income tax made within the accounting year. It deducts all expenses from revenue as well as interest expenses and operating expenses except for income tax. Idris (2015) used Profit after Tax (PAT) as one of its procedures of financial performance and found a strong positive relationship between recapitalization and Profit before Tax (PAT). Profit before Tax (PBT) was utilised in this study because profit before tax is within the control of management as tax expenditure is determined by the regulatory environment and fixed as a certain percentage of assessable profit.

Assets are items of economic value, which are expended over time to yield a benefit for the owner. If the owner is a business, these assets are usually documented in the accounting records and appear in the Statement of Financial Position (SFP) of the business. The Conceptual framework (2018) defined an asset as a resource controlled by an entity as an outcome of past events from which future economic profits are expected to flow to the entity. Adedeji, Babatunde and Adekanye (2015) found a significant relationship between the increase in Shareholders Fund (SF) and measures of profitability, for instance, Total Assets and Profit After Tax. Adedeji, Babatunde and Adekanye's work was in the Nigerian banking sector hence this study seeks if a relationship exists between the Fund (SHF) and Total assets in the insurance industry. 
Capital employed, also known as funds employed, is the worth of all the assets employed in a business or business unit and could be measured as a fraction of non-current assets to working capital or by subtracting current liabilities from total assets (Imeokparia, 2014). In the literature, it was revealed that there was no substantial work done on the impact of recapitalisation on capital employed within the insurance sector and the financial sector in general, hence, this objective form part of the researcher' exceptional contribution to knowledge (Adegbaju and Olokoyo, 2008).

\subsection{Recapitalisation and Financial Services Industry Performance}

According to Oyedokun (2013), Capital decision could be studied within the theoretical context established by Baltensperger (1973). In this context, the individual firm is assumed to make the most of its profit by choosing an optimal ratio of capital/debt within a competitive environment. Also, firms' capitalization aims to resolve the problem of the unsound financial system and to boost effective management in the financial system (Kanu and Isu, 2013). Capitalization is an imperative element of restructurings in the Nigerian financial or services industry because a firm with a strong capital base could absorb losses arising from non-performing obligations. Capitalization requirements may be realised through the alliance of existing firms or floating supplementary funds through the capital market (Adegbaju and Olokoyo, 2008; Mbizi, 2012).

According to Soludo (2004), recapitalisation is aimed at ensuring a diversified, robust and reliable banking industry where there is the safety of depositors' funds and re-assurance of the banks' incessant play of the dynamic intermediation role in the economy. Rose (2001) argued that a fair assessment of any bank's performance ought to have start by gauging the objectives, either long or short, set by management and stockholders of the company.

Pandey (2005), Oke (2006) and Gale (2010) describes liquidity as the active and lifeblood of any business. According to Oladejo and Oladipupo (2011), the current ratio gauges the relationship between current asset and current liabilities and is presented as current assets divided by current liabilities. While the quick asset ratio only considered the relationship between liquid assets that can be quickly converted into cash available to meet short term liabilities. Also, the study explicated that there must be a trade-off between the management of a firm's liquidity state and its profitability position as well. As more money is injected into the business, more profit would be recorded (Sanni, 2006; Sanni and Adereti, 2012).

Previous studies have shown the utilisation of financial indicators such as ROE, ROA, EPS, however, there have been conflicting interpretations amongst academics on the advantage of one indicator over others as a measure of profitability. In addition, Ahmed (2015) identified Net Interest Margin, Return on Assets(s) and Return on Equity as a good measure of profitability and this was previously supported by Goudreau and Whitehead (1989) and Uchendu (2005). Profitability measures, according to Kenn, Juliet and Henry (2006) and Akinola (2008) includes Profit before Tax, Profit after Tax, ROE, Rate of Return on Capital and Return on Assets. However, this paper used Premium Income, Profit before Tax to measure the profitability and the scope while the strength of insurers is being measured by Total Assets (TA) and Capital Employed.

\subsection{Theoretical Review}

There are several theoretical frameworks within which we can situate the impact of recapitalization on the financial performance of insurance companies in Nigeria. Some of these theories are the concentration theory, the value increasing theory, the value creation theory, the expected bankruptcy cost theory, the signalling theory and the risk-return hypothesis theory. In this section, we look at the expected bankruptcy theory, the signalling theory and the risk-return hypothesis theory as they are the most applicable theory to the research.

\subsubsection{Expected Bankruptcy Cost Hypothesis}

According to Jaros and Bartosova (2015), this hypothesis is derived from the proposition of Modigliani and Miller (Modigliani and Miller, 1963). M-M II argues that firms could intensify their value by borrowing and relishing high tax benefits. However, leverage beyond a certain point wears down the tax benefits and open up firms to financial distress and insolvency. Therefore, firms seek to find a balance between the suitable levels of leverage which reduces risk. Hence, in times of the high possibility of bankruptcy, insurers hold more equity to bolster them against likely financial distress and bankruptcy (Berger, 1995; Athanasoglou, Brissimis and Delis, 2008). Therefore, an upsurge in an insurer's capital may be an effort to pre-empt a likely crisis linked with high leverage or to tackle insurers' inability to take on complex risks leading to capital flight.

\subsubsection{Signaling Theory}

Ross (1977) promoted the signalling theory by disagreeing that firms would increase their total equity capital mix if they are positive about the future, thus increase their equity holding to signal their optimistic potentials for the future (Berger, 1995). When the National Insurance Commission raises the minimum capital requirement. It indicates that insurers that meet this requirement can now undertake complex risks with high sum insured and more profitable underwriting ventures in the future.

\subsubsection{Risk-Return Hypothesis}

The risk-return tradeoff assumes that markets are efficient, and no alpha-profit could be found: if a higher estimated 
return can be found there will be a rush to buy this security and the price of the security will increase. If the investor then buys the security when the price has already risen, she can expect a fair return given the risk taken, but no more than that. Similarly, security with too high-risk relative to the price, there will be an urgency to sell and the price will decrease until the risk matches the return of the stock and equilibrium is reached. This is the basic postulation of the risk-return trade-off, the investor expects a higher return when taking on securities with higher risk.

The concept of the risk-return tradeoff is used to explain the connection between risk and return. The hypothesis states that potential return increase when risk increases, and so this relationship is linear. An investor is only accepting taking on more risk if rewarded by a higher rate of return. Markowitz explains this in his paper Portfolio Selection: Efficient Diversification of Investments by stating that an investor's utility function must be quadratic: $U=c+a R+b R^{2}$, this is, if an investor prefers smaller standard deviation to larger standard deviation (expected return remains the same) then, given that the investor a) maximize the expected value of some utility function and b) her choice among portfolios depends only on her expected return and standard deviation (Markowitz, 1959).

Moreover, low levels of uncertainty are associated with low potential returns and vice versa and therefore the risk-return tradeoff states that an investor can only earn high returns if she is willing to take the risk of losing the investment made. This, of course, causing a discussion of risk aversion: all investors are risk-averse, but the degree of risk aversion differs. The risk an investor takes on is the price she is paying for potential return: we assume that if the risk premium were zero, the investor would not be keen to invest any money in that portfolio. Thus, theoretically, there must always be an optimistic risk premium to induce risk-averse investors to hold a risky portfolio instead of investing all her money in risk-free assets (Bodie, Kane and Marcus, 2011).

Summarily, this proposition is grounded in the economic theory of the link between risks and returns. The risk-return tradeoff theory assumes that the bigger the expected risk, the greater the expected return. This assumption is a part of the Modern Portfolio Theory introduced by Harry Markowitz, where he stated that all investors are risk-averse and will choose a portfolio with lower risk when choosing between two portfolios with the same rate of return (Markowitz, 1959). Rational investors assume yields to correspond with the amount of risk taken. Thus, increasing a firm's leverage (i.e., increased risk) should lead to higher earnings and vice versa (Stephen et al., 2018). Hence, if insurance companies expect increased returns, there would also be a matching increase in their risk taken by growing their capital base.

\section{Material and methods}

This study adopts the ex post facto research strategy. According to Samuel and Iyodo (2011), Adebisi and Samuel (2012), and Iyodo et al. (2020), ex post facto research is a systematic empirical study in which the researcher does not in any way control or manipulates the independent variables because the situation of study has already taken place. Furthermore, the study adopted the purposive sampling method to work out a sample size of 12 insurance companies contributing approximately $74 \%$ of the total insurance industry revenue in 2018 . The choice of purposive sampling is to enable the researcher to get enough publicly obtainable information on recapitalization and financial performances of selected insurance firms. Data for this study was from secondary sources through the instrument of documentation. Documented information majorly from the National Insurance Commission (NAICOM), The Nigerian Insurers Association (NIA), The Nigerian Stock exchange and company annual reports.

\subsection{Model Specification and Measurements of Variables}

In this study, five key measures were employed: one independent variable, Shareholder's fund (SHF) and four dependent variable Gross Written Premium, Profit before Tax (PBT), Total Assets (TA) and Capital Employed (CE). Having stated the theoretical context of the panel data analysis, we present our model as follows:

$$
\begin{aligned}
& G W P=\beta_{0}+\beta_{1} S H F \ldots \ldots \ldots \ldots \ldots \ldots \ldots \ldots 1 \\
& P B T=\beta_{0}+\beta_{1} S H F \ldots \ldots \ldots \ldots \ldots \ldots \ldots \ldots .2
\end{aligned}
$$

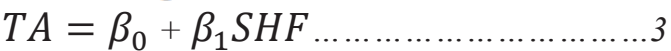

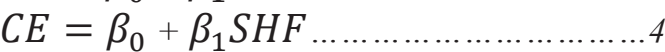

Where GWP denotes Gross Written Premium; SHF stands for Shareholder's fund and CE means Capital Employed. TA stands for Total Assets; PBT=Profit before Tax while $\beta_{0}$ and $\beta_{1}$ are Slope and Intercept of shareholder's fund, respectively.

Gross Written Premiums are the premiums registered on the books of an insurer or reinsurer at the time a policy is issued and paid for (Gospel and Benson,2018). Total assets are the total amount of assets owned by a person or entity. Assets are items of economic value, which are expended over time to yield a benefit for the owner (Adedeji, Babatunde and Adekanye, 2015). Capital employed, also known as funds employed, is the total amount of capital used for the acquisition of profits by a firm or project. It is the value of all the assets employed in a business or business unit and can be calculated by Non-current assets to working capital or by subtracting current 
liabilities from total assets (Imeokparia, 2014). Profit before tax (PBT) is a measure that looks at a company's profits before the company must pay corporate income tax (Stephen et al., 2018). Shareholders' funds refer to the amount of equity in a company, which belongs to the shareholder (Imeokparia, 2014; Idris, 2015; Oloye and Osuma, 2015).

\section{Result and Discussion}

This research work seeks to understand the factors and determinant of the performance of insurance companies in Nigeria, for this research work, the sample selection was a judgmental sampling of 12 best performing insurance firms by revenue. The time range of the data selection was 10 years covering 2009 to 2018 . For this research work, two of the prominent methods for establishing relationships, namely correlation and simple linear regression was deployed.

Prior to deploying the model, this research work made an effort to test some of the assumptions of correlation and regression which includes normality test, independencies and linearity of the variables. It is, however, worthy to note that all analysis to this work is carried out in E-Views environment at $5 \%$ level of significance which matches a $95 \%$ confidence interval.

The result of the analysis is presented below:

Table 1: Descriptive statistics of important variables

\begin{tabular}{lccccc}
\hline & $C E$ & $G W P$ & $P B T$ & $S H F$ & $T A$ \\
\hline Mean & 19707912 & 12855312 & 1219074. & 9834842. & 31617919 \\
Median & 9313437. & 9190634. & 826489.0 & 7439234. & 19336901 \\
Maximum & $2.96 \mathrm{E}+08$ & 87000000 & 13448965 & 47060563 & $3.13 \mathrm{E}+08$ \\
Minimum & -4060438. & 1106607. & -7825320. & -3172217. & 3435089. \\
Std. Dev. & 39711040 & 13627281 & 2719578. & 7469536. & 43644190 \\
Skewness & 5.193589 & 3.218149 & 0.957614 & 2.377669 & 4.179887 \\
Kurtosis & 32.16158 & 15.57584 & 8.892714 & 11.58463 & 23.91561 \\
Jarque-Bera & 4751.528 & 989.5733 & 190.3612 & 477.5328 & 2515.603 \\
Probability & 0.000000 & 0.000000 & 0.000000 & 0.000000 & 0.000000 \\
Sum & & & & & \\
Sum Sq. Dev. & $1.86 \mathrm{E}+17$ & $2.19 \mathrm{E}+16$ & $8.73 \mathrm{E}+14$ & $6.58 \mathrm{E}+15$ & $2.25 \mathrm{E}+17$ \\
Observations & 120 & $1.53 \mathrm{E}+09$ & $1.45 \mathrm{E}+08$ & & 120 \\
\hline
\end{tabular}

Owning to the fact that our variables are on a continuous scale of measurement, we applied the mean, standard deviation and the Jarque-Bera statistics amongst other metrics. The Capital Employed (CE) was quoted at an average $(M=19707912, S D=39711040)$, the average Gross Premium Written across the 12 insurance company sampled stands at $(M=12855312, S D=13627281)$ while their Profit Before Tax (PBT) stands at an average $(M=1219074, S D=2719578)$. The minimum PBT is quoted at -7825320 which implies that some insurance firms are reporting loss even before tax. The average Total Asset (TA) of the sampled insurance company is $(M=31617919, S D=43644190)$ while the average Share Holder's Fund (SHF) stands at $(M=9834842$, $S D=7469536$ ), again the minimum SHF was -3172217 , meaning that some insurance firms have accumulated losses in their books. The Jarque-Bera test of normality helps us test whether the collated data and variables satisfy the normality assumption, a significant assumption of regression analysis, it is expected that the predictor, SHF is normally distributed with $\left(\mu, \boldsymbol{\sigma}^{\mathbf{2}}\right)$.

Table 2 below shows the result of the models formulated for the study to assess the impact of recapitalisation on the financial performances of insurance firms in Nigeria. 
Table 2:Summary of Least-square Regression Result

\begin{tabular}{|c|c|c|c|c|}
\hline Variables & $\begin{array}{c}\text { Model 1 } \\
\text { GWP }=\beta_{0}^{+} \\
\beta_{1} S H F\end{array}$ & $\begin{array}{c}\text { Model } 2 \\
P B T=\beta_{0}+ \\
\beta_{1} S H F\end{array}$ & $\begin{array}{c}\text { Model } 3 \\
\text { TA }=\beta_{0}+\beta_{1} S H F\end{array}$ & $\begin{array}{c}\text { Model } 4 \\
C E=\beta_{0}+ \\
\beta_{1} S H F\end{array}$ \\
\hline $\boldsymbol{\beta}_{0}($ constant $)$ & -1065553 & -1349313 & -14527192 & -23458200 \\
\hline $\begin{array}{c}\boldsymbol{\beta}_{1} \\
\text { (Coefficient) }\end{array}$ & 1.402594 & 0.258634 & 4.692003 & 4.371687 \\
\hline Std. Error & 0.107518 & 0.023615 & 0.321924 & 0.277285 \\
\hline t-Statistic & 13.04526 & 10.95193 & 14.57490 & 15.76602 \\
\hline Prob. & 0.0000 & 0.0000 & 0.0000 & 0.0000 \\
\hline \multicolumn{5}{|l|}{ Fitness: } \\
\hline $\mathrm{R}^{2}$ & 0.590532 & 0.504087 & 0.644839 & 0.678095 \\
\hline Adjusted $\mathrm{R}^{2}$ & 0.587062 & 0.499884 & 0.641803 & 0.675367 \\
\hline S.E. R & 8736360 & 1918870 & 26120856 & 22530885 \\
\hline Sum $^{2}$ resid & $9.01 \mathrm{E}+15$ & $4.34 \mathrm{E}+14$ & $7.98 \mathrm{E}+16$ & $5.99 \mathrm{E}+16$ \\
\hline $\begin{array}{c}\text { Log- } \\
\text { likelihood }\end{array}$ & -2087.225 & -1905.334 & -2200.156 & -2200.912 \\
\hline F-statistic & 170.1788 & 119.9447 & 212.4277 & 248.5672 \\
\hline $\begin{array}{l}\text { Prob(F- } \\
\text { statistic) }\end{array}$ & 0.000000 & 0.000000 & 0.000000 & 0.000000 \\
\hline
\end{tabular}

From the result of parameter estimation in model one, we can infer that SHF is positively affecting and contributing to the GPW in the sampled insurance firms as the model result showed that a unit increase in the SHF resulted in about 1.4 unit increase in the GPW of the selected insurance firms. Therefore, we reject the null hypothesis that there is no substantial relationship between SHF and GWP. We conclude that the SHF is positively affecting and contributing to the GPW of insurance firms. For model two, the result of parameter estimation shows that SHF is positively contributing to the PBT in the sampled insurance firms, the model result showed that a unit increase in the SHF resulted in about 0.26 unit increase in the PBT of the selected insurance firms. Therefore, we reject the null hypothesis that there is no significant relationship between SHF and PBT. We conclude that the SHF is positively affecting and contributing to the PBT of insurance firms in Nigeria.

Similarly, in model three, the result shows a positive relationship between SHF and Total assets of sampled insurance firms in Nigeria. The model result showed that a unit increase in the SHF resulted in about 4.69 unit increase in the TA by the selected insurance firms across the years under review. Also, from the estimation in Table 2, the null hypothesis which states that there is no significant relationship between Shareholders' fund and capital employed of the insurance firms in Nigeria is hereby rejected. A unit increase in the SHF resulted in about 4.37 unit increase in the $\mathrm{CE}$ by the selected insurance firms during the period under review which also means that the SHF has a positive and significant effect on the capital employed of insurance firms in Nigeria.

Also, in Table 2, the R-square and the adjusted R-square which estimates the extent of variation in the dependent variable that is being accounted for by the predictor variable shows that the models are a good fit. The R-square and adjusted R-square for model 1 stands at 59\% and 59\% while for model 2, stands at 50\% and 50\% respectively. this fact was also supported by the result obtained in our correlation test. We also infer that SHF explains about $65 \%$ and $64 \%$ of the variation in TA using the R-square and the adjusted R-square respectively. SHF account for $68 \%$ in CE concerning $\mathrm{R}$ square and adjusted $\mathrm{R}$ square. The regression analysis of variance is significant for the four models, owning to $\mathrm{p}$-value $<1 \%$ [Prob(F-statistic)], implying that the proposed regression models are a good fit.

Table 3 below present the correlation matrix of the variables used in the study Table 3: The Correlation matrix of the important variables

\begin{tabular}{crrrrr}
\hline & $S H F$ & $C E$ & $G P W$ & \multicolumn{1}{c}{$P B T$} & \multicolumn{1}{c}{$T A$} \\
\hline SHF & 1 & 0.8248319 & 0.7742537 & 0.715699 & 0.8030184 \\
CE & & 1 & 0.8797827 & 0.6296421 & 0.92975543 \\
GWP & & & 1 & 0.6686542 & 0.961834 \\
PBT & & & & 1 & 0.6433907 \\
TA & & & & \\
\hline
\end{tabular}

The correlation matrix shows that the leading diagonal is 1, meaning that the correlation between a variable and itself is 1 (a perfect one). Overall, it is expected that there exists a strong relationship between SHF across the 4 predictors, the result obtained showed that there exists a strong relationship between the dependent variable SHF and the four predictors. CE recorded the strongest relationship with SHF at $(r=0.8283)$, followed by TA $(r=$ $0.80300)$ and GPW at $(\mathrm{r}=0.7742)$ and PBT at $(0.7157)$ in that other. 


\section{Conclusion and Recommendations}

The factors and determinant of the performance of insurance companies in Nigeria is the subject of this research work, the researcher proposes a joint tool of Pearson's correlation coefficient and simple linear regression to understand the relationship between GPW, PBT, TA, CE and SHF. Furthermore, we observed that SHF explained more variation in CE and TA respectively, meaning that the CE and TA models are the strongest amongst the four models fitted. We can consequently infer that an increasing Shareholders Fund (SHF) would lead to a significant increase in the Total Assets (TA) and Capital Employed (CE) of insurance firms and vice versa. Increasing/decreasing shareholders Fund (SHF) would also result in Increasing/decreasing Gross Premium Written (GPW) and Profit Before Tax (PBT) but not as significant as in the case of TA and CE.

Stephen et al. (2018) in their study looked at the beneficiaries of the bank recapitalization exercise in Ghana and found a strong and positive relationship between recapitalization and financial performance as measured by Return on Assets (ROA), Return on Equity (ROE) and Profit before Tax (PBT). Similarly, Idris (2015) found a positive but significant relationship between capital size and the Profitability of insurance firms in Nigeria. This is also consistent with the findings of Adedeji, Babatunde and Adekanye (2015) that found a strong and positive relationship between recapitalization policy as measured by Shareholders Fund (SHF) and Profitability of Nigerian banks as measured by Profit after Tax (PAT) and Total Assets (TA). This study, therefore, investigated the impact of recapitalization on the financial performance of insurance firms and its findings are consistent with the existing body of research on recapitalization and the financial performance of firms.

Arising from the above and based on the outcome of the study, the study advances some recommendations for policy, practice and academic research. The National Insurance Commission (NAICOM) should have the will to conclude on the ongoing recapitalization exercise in the Nigerian insurance industry as this would enable Insurers to underwrite bigger risks in the sector and help forestall capital flight. Insurers should embrace regular recapitalization exercise and take initiatives to increase its capital size without waiting to be prompted by regulators because recapitalized firms are more likely to be attractive to investors, employees, customers and other relevant stakeholders than firms with thin capital structure. Recapitalization plan should be included in insurance companies' strategic plans.

Investors should engage experts to investigate the financial discipline, quality \& competencies of top-level management and the quality of corporate governance in their investee firms before committing money to any recapitalization exercise. Furthermore, investors should hold management accountable to ensure that envisaged gains from recapitalization exercise are achieved. The government should sanitize the regulatory environment to ensure that competent leadership is engaged to run the affairs of the regulatory institutions. This is to ensure that regulators have the skill and manpower required to carry out supervisory role over recapitalization exercise and forestall sharp practices by firms to meet recapitulation requirement during recapitalization exercise. Since the capital base is not a guarantee for financial performance in the insurance industry and may not also create a sound insurance industry, stakeholders must pay attention to other salient issues with a remote impact on financial performance. Some of these remote issues are customer satisfaction, service efficiency, technology deployment to enhance customer experience, regular dividend declaration and quality of staff.

\section{References}

Abubakar, A., Usman, H. and Sulaiman, I. (2018). Effect of Firms Characteristics on the Financial Performance of Listed Insurance Companies in Nigeria. Journal of History and Archaeology 3(1):1-9

Adebisi, J.F. and Samuel, S.E. (2012). Effects of taxes on a dividend payout ratio of banks in Nigeria. Salem Journal of Management Science, 1(1): 88-106.

Adedeji, O.L., Babatunde, M.A. and Adekanye, T. (2015). Recapitalization policy and performance of banks in Nigeria. International Journal of Economics, Commerce and Management, 3(4): 1- 12.

Adegbaju, A.A. and Olokoyo, F.O. (2008). Recapitalization and Bank's Performance: A Case Study of Nigerian Banks. African Economic and Business Review 6 (1): 68-75.

Ahmed (2015) Effect of Capital Size on the Profitability of listed insurance firms in Nigeria. African Journal of Business Management $10(5): 109-113$.

Akinola (2015) Nigeria: Recapitalization: Industrialist Hails FG ThisDay News Paper retrieved from https://allafrica.com/stories/200502240092.html

Alajekwu, U.B. and Obialor, M.C. (2014). Nigerian Bank Recapitalization Reforms: Effects on Banks and the Economy (2002 -2012). International Journal of Managerial Studies and Research. 2(2): 48-56.

Alalade, Y.S., Adekunle, O.A. and Oguntodu, J.A. (2016). Empirical Investigation of Impact of Recapitalization as a Predicate of Bank Performance: A Case of Nigeria. International Journal of Advanced Academic Research, 2 (2): 1-19.

Athanasoglou, P.P., Brissimis, S.N. and Delis, M.D. (2008). Bank-specific, industry-specific and macroeconomic determinants of bank profitability. Journal of International Financial Markets, Institutions and Money, 18 (2):121-136. 
Bakare A.S, (2011). A Theoretical Analysis of Capital Formation and Growth in Nigeria, Far East Journal of Psychology and Business, Far East Research Centre, 3(2): 11-24.

Baltensperger (1973). Alternative approaches to the theory of the banking firm. Journal of Monetary Economics, $6(1): 1-3$.

Berger, A.N. (1995). The profit-structure relationship in banking-tests of market-power and efficient-structure hypotheses. Journal of Money, Credit and Banking. 27(2):404-431

Bodie Z., Kane A. and Marcus A., (2011). Investment and Portfolio Management. McGraw-Hill/Irwin.

Conceptual framework (2018) The Conceptual Framework for Financial Reporting retrieved from https://www.ifrs.org/-/media/project/conceptual-framework/fact-sheet-project-summary-and-feedbackstatement/conceptual-framework-project-summary.pdf

Eddie (2018). Operators Lament Poor Performance by Insurance Sector. Thisday newspaper 12(490): 50-60.

Gale (2010). Diagnosis of the causes of business failures: a Nigerian experience. International Journal of Management and Innovation, 2(1): 31-40.

Gospel, J. and Benson, P. (2018). Stakeholders satisfaction and performance of insurance firms in Nigeria. Journal of Economics and Finance, 9(6):6 -13.

Goudreau, R.E, and Whitehead, D.D. (1989). Commercial Bank Profitability: Improved In 1988. Economic Review -Federal Reserve Bank of Atlanta; Atlanta, 74(4), 34

Idris A. (2015). Effect of capital size on the profitability of listed insurance firms in Nigeria. African Journal of Business Management, 10(5), 109 -113.

Imeokparia, L. (2014). Post-merger acquisition and performance of deposit money banks in Nigeria. Journal of Business Management, 16(5): 18 -25.

Iyodo, B.Y., Samuel, S.E., Adewole, C., and Ola, P.O. (2020). Impact of Non-life Insurance Penetration on the Economic Growth of Nigeria. Research Journal of Finance and Accounting, 11(2):40-50

Iyodo, B.Y., Samuel, S.E. and Inyada, S.J. (2018). Effect of insurance industry performance on economic growth in Nigeria. International Journal of Business and Finance Management Research 6(3): 22-33

Jaros, J. and Bartosova, V. (2015). To the Capital Structure Choice: Miller and Modigliani Model. Procedia Economics and Finance, 26 (2015): 351-358.

Kanu, C. and Isu, H.O. (2013). Recapitalization policy and Performance of banks in Nigeria 1970 - 2010: An Assessment. International Review of Management and Business Research, 2(3): 643-652.

Kari, 2019 NAICOM Introduces Tier- Based Recapitalisation For Insurers Set January 1, 2019, As Implementation Date. BusinessToday - Retrieved from: https://businesstodayng.com/fg-introduces-tierbased-recapitalisation-for-insurers-set-january-1-2019-as-implementation-date/ (access 21 February 2020).

Kenn N., Juliet I. and Henry W.A. (2006). Effects of Recapitalization on Commercial Banks Survival in Nigeria: Pre And Post Camel Analysis. European Centre for Research Training and Development, 3(9): 12-30.

Markowitz, H. (1959). Portfolio Selection. The Journal of Finance, 7(1): 77-91.

Mbizi, R. (2012). Analysis of the Impact of Minimum Capital Requirements on Commercial Bank Performance in Zimbabwe. International Journal of Economics and Business Research, 1(4): 181-193.

Modigliani, F. and Miller, M.H.(1963). Corporate Income Taxes and the Cost of Capital: A Correction. The American Economic Review, 53(3): 433-443.

Oke, O.A. (2006). Banking Consolidation in Nigeria and the Strategies for Generating Better Returns. Searchwarp.com.

Oladejo, M.O. and Oladipupo, A.U. (2011), Capital regulation and the performance of the Nigerian banks: the need for review. Journal of Emerging Trends in Economics and Management Sciences, 2(3): 215 - 224

Oloye, M.I. and Osuma, G. (2015). Impact of mergers and acquisition on the performance of Nigerian banks. Journal of business and finance management research, 1(4):23-40.

Oyedokun A. (2013). Trend Analysis of the Effect of Capital Base Requirement on Profit Generating Capacity and Operational Efficiency of Selected Commercial Banks in Nigeria. Research Journal of Finance and Accounting, 4(17), 142-153.

Pandey, I. M. (2005). Financial management. 9th edition. India; Vikas Irish Publication

Rose P.S. (2001). Commercial Bank Management. 5th Edition, McGraw-Hill Irwin.

Ross (1977) Testing the Pecking Order Theory and the Signaling Theory Approach." the Bell Journal of Economics 8 (1977): 23-40.

Samuel, S.E. and Iyodo, B.Y. (2011). The effects of interest rates volatility on development stock: A time series analysis. Kogi State University Journal of Public Administration 1(1):38-47

Sanni, M.R, Ebo, B.O. and Adereti A. S. (2012). Post Consolidation Profitability Ranking of Nigerian Banks. European Journal of Humanities and Social Sciences, 12(1), 554 - 572.

Seyi and Oluwatoba (2019). New Capital Requirement for Nigerian Insurance Companies: What you Should Know Retrieved from https://www.mondaq.com/Nigeria/Insurance/812392/New-Minimum-CapitalRequirement-For-Nigerian-Insurance-Companies-What-You-Should-Know 
Soludo, C. (2004). Consolidating the Nigerian Banking Industry to Meet the Development Challenges of the 21st Century. Being an address delivered to the Special Meeting of the Bankers' Committee, held on July 6, at the CBN Headquarters, Abuja.

Stephen, Y., Hanania, D., Eric, B.Y. and Mark, K. (2018). Bank recapitalization in Ghana, who benefit the more? Global journal of management \& business research, 18 (6): 1-11.

Uchendu, O.A. (2005). Banking Sector Reforms \& Bank Consolidation: The Malaysian Experience. Bullion, 29(2):12-16

Ufomadu, (2012). Nigerian Insurance Industry: Overview, Challenges and Opportunities Retrieved from https://www.capitalmarketsinafrica.com/nigerian-insurance-industry-overview-challenges-andopportunities/

Ugwuanyi, (2012) Capital Structure and Market Values of Companies. European Journal of Business and Management, 4(21): 49-54 